\title{
Durian Rind Micro Composter Model: A Case of Kampung Durian, Ngrogung, Ponorogo, Indonesia
}

\author{
Haris Setyaningrum ${ }^{1, *}$, Atika Rukminastiti Masrifah ${ }^{2}$, Adib Susilo $^{2,3}$, and Imam Haryadi $^{2}$ \\ ${ }^{1}$ Department of Agrotechnology, University of Darussalam Gontor, Siman Road Km 5, \\ Ponorogo, East Java, Indonesia 63471. \\ ${ }^{2}$ Department of Islamic Economic, University of Darussalam Gontor, Siman Road Km 5, \\ Ponorogo, East Java, Indonesia 63471. \\ ${ }^{3}$ Kulliyah of Economics and Management Sciences, International Islamic University Malaysia, \\ Gombak, Selangor, 553100 Malaysia.
}

\begin{abstract}
The case of waste from durian rind in Ngrogung, Ngebel, Ponorogo, Indonesia increased significantly per year. Agglomerations and decomposition of durian rind surrounding agro park caused air pollution and bad view in park areas. The decomposition of durian rind is very important to reduce those impacts. The micro composter model in Kampung Durian consisted of three main components. The first component was drying area with cemented ground. The drying area was set to accommodate $1 \mathrm{t}$ fresh durian rind per day. The materials come from surrounding areas of agro park. The second was a machine house with one ton material capacity per day. The third was a composter house consisted of composter tube and packing area. The result of the micro composter house showed a cleaning agglomeration of durian rind from Ngebel lake and surrounding areas. In addition, the model produced liquid organic fertilizer and compost. A cycle of composting was $30 \mathrm{~d}$ in the dry season. Amount $1 \mathrm{t}$ of durian rind decomposition resulted of $100 \mathrm{~L}$ liquid organic fertilizers and $50 \mathrm{~kg}$ compost. The result of composter had a direct impact to control waste problems in Ngebel and surrounding areas.
\end{abstract}

Keywords: Agro park, compost durian, Durio zibethinus, micro composter house, organic fertilizer

\section{Introduction}

Durian is an iconic product of Ponorogo, East Java, Indonesia. It is produced in Ngebel. Production in the last $2 \mathrm{yr}$ rises significantly from $1969.2 \mathrm{t}$ in 2016 to $9871.9 \mathrm{t}$ in 2017 [1]. The Ponorogo region, located in $111^{\circ} 17^{\prime}-111^{\circ} 52^{\prime} \mathrm{E}$ and $07^{\circ} 49^{\prime}-08^{\circ} 20^{\prime} \mathrm{S}$, consisted of two different levels of geographic, i.e. lowland and upland [1]. Ngebel is the new tourist destination that is integrated with an agro park named Kampung Durian. It is located 1.5 $\mathrm{Km}$ from Ngebel lake. The rind composter is potential to develop in Kampung Durian.

The higher produced durian the higher its rind. The durian composed of $75 \%$ of rind and the remains are seed and flesh [2]. For example, the durian rind in 2017 was $6910.33 \mathrm{t}$.

\footnotetext{
*Corresponding author: abuharist@gmail.com or haris.setyaningrum@unida.gontor.ac.id
} 
These huge numbers of rind caused several problems in Ngebel as a tourism destination, including air pollution by chemical and biological decomposition process and health problems which coming from insects [3]. Reference [4] stated waste has the potential to pollute the environment, among others, because it produces leachate and gas. The waste can pollute three environmental media: the atmosphere, lithosphere, and hydrosphere. The local government which responsible to overcome this rising issue does not have any specific composter. Design and build a specific composter is very important.

The rind of durian is sources of lignin, cellulose, and hemicelluloses [4, 5]. Otherwise, rind of durian are sources of cellulose with high economic value such as textile fiber, biopesticide, and organic compost [6-8].

The objective of this study was to make a role model of micro composter house of rind durian which applicable to other communities.

\section{Material and method}

\subsection{House components}

The experiment was conducted from September 2019 to August 2019. The house of micro composter located in Kampung Durian, Ngrogung in the upland area where easy to water access and distribution. The house was separated into three different parts: i) Shelter for drying rind. ii) Machinery room. iii) Fermentation room. To make easy for moving and handling, those three parts were connected.

\subsection{Durian rind sources}

The rind of durian in the house composter were obtained from two places, which were Kampung Durian Ngrogung and Ngebel lake. Kampung Durian only supplied a small amount of durian rind. While, the Ngebel lake as tourism destination provided continuously even was not durian season.

\subsection{Composting process}

The rind was deposit in the shelter to get dried rind material. A cycle of composting process was designed for one ton of fresh durian rind. Amount $1 \mathrm{t}$ of fresh rind dried for $3 \mathrm{~d}$ to $4 \mathrm{~d}$ in dry season. The dried rind was cut into small pieces used cutter machine. The small pieces of dried rind was fermented with probiotic and tap water, put in $100 \mathrm{~L}$ container under anaerobe condition. Fermentation process was conducted for $30 \mathrm{~d}$ with weekly observation especially for fresh weight material. The total container used in this research was eight containers, the materials were distributed equally.

\section{Results and discussions}

A cycle of composting process since drying to fermented compose was $30 \mathrm{~d}$ to $35 \mathrm{~d}$ depend on water content of durian rind. This result inline with Kinantan et.al [3]. The details of a cycle composting process of durian rind was presented in Figure 1. 


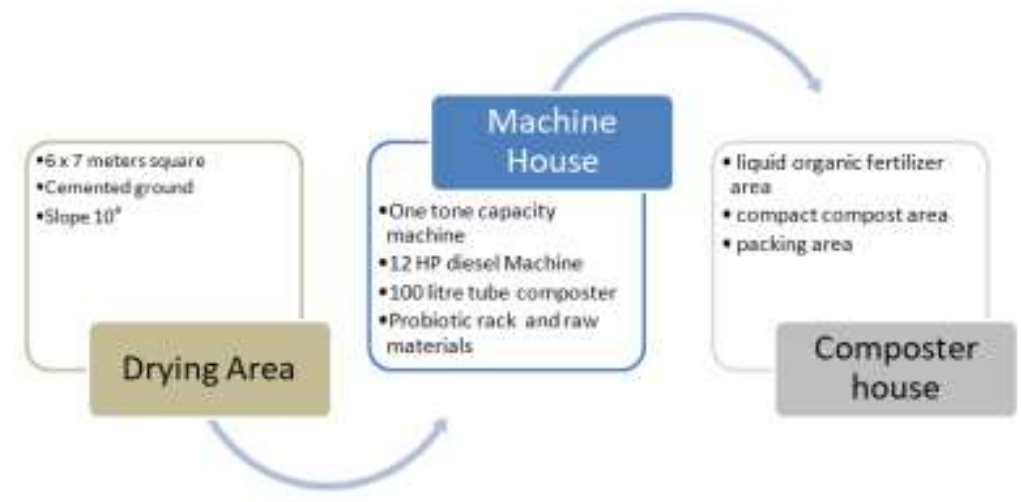

Fig 1. Scheme of processing durian rind decomposition in Micro Composter House

The last product of composting were liquid compost and solid compost which reach up to $80 \%$ of total product. The rest of $20 \%$ product was waste material that used for another purposed with specific processed, included biopesticides [9].

Amount $1 \mathrm{t}$ material resulted $100 \mathrm{~L}$ of liquid organic compost (fertilizer) and $\pm 50 \mathrm{~kg}$ solid material. These current result was not categorized as a solid organic fertilizer and final waste, but as solid organic that has function as organic fiber. This type of fiber useful for reinforcement of many materials such as concrete. While as a natural source of cellulose, the durian rind has not been explored yet $[5,10]$. Other product of composting was not observed yet. The other product may useful for pesticide, as stated by Kusumaningtyas et.al [7] and edible material for many purposed as stated by Amaliyah [11].

The cycle of composting in Ngrogung had several benefits such as for reducing agglomeration of durian rind as waste in Ngebel lake and surrounding areas. It was calculated when a cycle of composting in Ngebel take a ton fresh material of durian rind and can be increased depend on the availability of drying space.

Another benefit of this composting were availability of organic fertilizer for durian in such area which increased durian production through optimized and maximized of organic fertilizer. The pesticide as vital component in cultivation of durian, also be covered from composting product with some treatments [12].

\section{Conclusion}

The micro composter model in Kampung Durian Ngrogung was helpful for farmers in Ngrogung and surrounding areas of Ngebel lake, Indoensia. The benefits were reducing agglomeration of durian rind and providing organic fertilizer. Future studies of micro composter efficiency was needed to get a higher impact for durian farmers.

\section{References}

1. P. Badan Pusat Statistik. Ponorogo Dalam Angka 2018. (2018).[in Bahasa Indonesia].https://ponorogokab.bps.go.id/publication/2018/08/16/7400511f763983ffb ab97edf/kabupaten-ponorogo-dalam-angka-2018.html

2. P. Damanik, Volmer; Musa, Lahuddin; Marbun. Agroekoteknologi. 2,1:455-461 (2013). [in Bahasa Indonesia]. https://media.neliti.com/media/publications/97671-IDpengaruh-pemberian-kompos-kulit-durian-d.pdf

3. B. Kinantan, A. Rahim Matondang, J. Hidayati. IOP Conf. Ser. Mater. Sci. Eng. 505,1:1-9(2019). https://doi.org/10.1088/1757-899X/505/1/012106 
4. K. Khoiron, A.N. Probandari, W. Setyaningsih, H.S. Kasjono, R.H. Setyobudi, O. Anne, Ann Trop \& Public Health S463, 23,3(A):60-67(2020). http://doi.org/10.36295/ASRO.2020.23316

5. P. Penjumras, R. B. A. Rahman, R. A. Talib, K. Abdan. Agric. Sci. Procedia, 2:237243(2014). https://doi.org/10.1016/j.aaspro.2014.11.034

6. R. Lubis, B. Wirjosentono. IOP Conf.Series Journal Physic Conf. Ser. 1232,012017:1-9(2019) . https://doi.org/10.1088/1742-6596/1232/1/012017

7. R.D. Kusumaningtyas, H. Suyitno, R. Wulansarie. Jurnal Penerapan Teknologi dan Pembelajaran, 15,1:38-43(2018). [in Bahasa Indonesia] https://doi.org/10.15294/rekayasa.v15i1.12576

8. S.N.B.B. Khalib, I.A.B.Zakarya, T.N.B.T. Izhar. IOP Conf. Ser. Mater. Sci. Eng. 551,012101:1-7(2019). https://doi.org/10.1088/1757-899x/551/1/012101

9. T. Arrizqiyani, R. Hidana, M.A. Sopian, R. Nurpalah, Meri. J. Phys. Conf. Ser., 1179,012174:1-5(2019). https://doi.org/10.1088/1742-6596/1179/1/01217

10. S. R. Masrol, M. H. I. Ibrahim, S. Adnan. Procedia Manuf., 2:171-180(2015). http://dx.doi.org/10.1016/j.promfg.2015.07.030

11. D. M. Amaliyah, J. Ris. Ind. Has. Hutan. 6,1:27-34(2014).[in Bahasa Indonesia]. https://doi.org/10.24111/jrihh.v6i1.1222

12. N. H. Hasem, S. F. Z. Mohamad Fuzi, F. Kormin, M. F. Abu Bakar, S. F. Sabran. IOP Conf. Ser. Earth Environ. Sci. 269,012019 (2019). https://doi.org/10.1088/1755$\underline{1315 / 269 / 1 / 012019}$ 